KozMA Zsolt 2002. Jézus Krisztus példázatai. Iránytü Alapítvány, Kolozsvár.

MÁRTONFFy MARCELl 2001. Az újszövetségi példázatok irodalma. Poétika és teológia. Akadémiai Kiadó, Budapest.

NAGY L. JÁNOS 1990. A megnyilatkozás nyelvi értékei. Szemiotikai Szövegtan 1: 29-34.

NAGY L. JÁNOS 2020. A kettős szillogizmus müködése kanonizált szövegekben. In: SzŐNYI ETELKA szerk., Biblia: korok, módszerek, kontextusok. Írások Benyik György 68. születésnapjára. JATEPress, Szeged. 481-491.

PorZIG, WALTHER 1962. Das Wunder Der Sprache. Francke Verlag, Bern.

ROZGONYINÉ MolNÁR EMMA - GALGÓCZI LÁSZLÓ - NAGY L. JÁNOS szerk. 1996. Absztrakció és valóság. Békési Imre köszöntése. JGYTF Kiadó, Szeged.

RUZSA IMRE 1984. Klasszikus, modális és intenzionális logika. Akadémiai Kiadó, Budapest.

Sion, Avi 1990/1996. Future logic: Categorical and conditional deduction and induction of the natural, temporal, extensional, and logical modalities. CreateSpace \& Kindle - Lulu, Geneva. TANDI LAJOS szerk. 2006. (A)miért föiskola a tanárképzö(.)? JGYF Kiadó, Szeged.

NAGY L. JÁNOS

Szegedi Tudományegyetem

\title{
Péntek János 80 éves
}

2021. július 14-én tölti be 80 . életévét PÉNTEK JÁNOS, a magyar nyelvtudomány kiemelkedő személyisége, az erdélyi magyar tudományosság büszkesége, nagykövete s jó ideje már doyenje is, a kolozsvári iskola emblematikus alakja, fontos könyvek és tanulmányok írója, a tudományos közélet lankadatlan szereplője, a kisebbségi magyar lét hiteles képviselője, tudós leírója és elemzője, az anyanyelvet mindig méltósággal és bátorsággal vállaló, nagyra becsült ember, kolléga és barát. Emberséges volta, morális tartása például szolgál. Az olvasók jól tudhatják: számos méltató írás jelent meg róla. Maga is többször nyilatkozott - az utódok számára okulásul szolgáló - kor- és tudománytörténeti tényektöl befolyásolt, alakított életútjáról, tudományos pályája alakulásáról. 70. évfordulója alkalmából köszöntő könyvvel ajándékozták meg tisztelöi. 2015-2016-ban megjelent az a kétkötetes, Történések a nyelvben a keleti végeken címü tanulmánygyüjtemény, amely az ő változatos tematikájú írásait tartalmazza. Ennek a tartalomjegyzéke önmagában is kedvcsináló az olvasáshoz, olyan színes és változatos a kínált paletta. PÉNTEK JÁNOS írásait olvasni azonban nemcsak szakmai szempontból jár többrendbeli haszonnal. Érdemes rámutatni írásmódjának stílusára is, amely az írások mindenkori témájától függően az igényes olvasónak a maga emelkedett választékosságával, nem ritkán költői, olykor a pátosz felé hajló voltával esztétikai örömöt is nyújt. Egyik könyvének A nyelv ritkuló légköre a címe. Mikor elöször olvastam, a találó metafora megragadott. A cím utalás a tőle emlegetett, a kisebbségek körében gyakori „megfélemlített anyanyelvhasználat” következményére (gondoljunk a hazai német kisebbség 1945 utáni sorsára). A moldvai példa világosan mutatja: ,[a] moldvai magyarok kétnyelvüsége a két nyelv kölcsönös szóbeliségében évszázadokon át fennmaradhatott, amikor azonban az egyik nyelv jogi státusában és standardként a másik fölé emelkedik, megállíthatatlanná válik a nyelvcsere" (2015-2016. 1: 25).

DOI: https://doi.org/10.18349/MagyarNyelv.2021.2.235 
A kalotaszegi körösfői családi háztól messze út vezetett a kolozsvári egyetemi katedráig és az erdélyi magyar tudományos és közéletben betöltött vezető különböző szerepkörökig, a Magyar Tudományos Akadémia külső tagságának elnyeréséig, az elismeréseit kifejező kitüntetések soráig. „Saját pályámat, melynek szintén megvoltak a kedvező pillanatai és a stagnálás vagy akár a reménytelenség időszakai, három tényező alakította. Az egyik, hogy Körösfön, Kalotaszegen születtem, olyan nyelvi környezetben, közösségben, amely sem a nyelvet, sem a hagyományt nem muzeális értékként őrizte, hanem azt kereste, hogyan tudja általa megújítani életét” (2015-2016. 1: 195). Egész életpályájára vonatkozó megállapítása, hogy „,[m]indenképpen kellett némi optimizmus és megszállottság (netán mazochizmus is) ahhoz, hogy az ember kisebbségi magyar léte mellett szakmaként is a magyarságtudományt válassza” (2015-2016. 1: 194). Hetvenévesen írta: „Sok tekintetben egyedül maradtam saját nemzedékemből, ezért is kellett és kell többet vállalnom, jóval nagyobb (szak)területen, szélesebb körü elkötelezettséggel, mint amennyit jól, jó lelkiismerettel el lehet végezni” (2015-2016. 2: 334). Mert „akik kívül vannak a tudomány nemzeti intézményrendszerén, óhatatlanul túlságosan is sok mindennel foglalkoznak. Ezzel magam is így vagyok" (2015-2016. 1:27). A kolozsvári egyetemen 2008-ban szünt meg a státusa: „Kegyvesztett lettem, és amint lehetett, kihasználták az alkalmat, hogy megszabaduljanak tőlem” (in: BolLA szerk. 2009. 3: 283). A „Nyugtalan számvetés hetvenévesen" találó fejezetcím jól fejezi ki azt az állapotot, amelyben a közösségéért és anyanyelvéért is felelősséget viselő tudós élte és éli életét. A nyugtalanság oka a magyarság erdélyi sorsa. Ezzel összefüggésben a szakma tekintetében például az, hogy „saját nemzedékemből nagyon kevesen voltunk, még kevesebben maradtunk meg, maradtunk itthon az átmenet időszakára” (2015-2016. 1: 10-11). Mindeme tények ismeretében még nagyobbnak látjuk egyébként is kiemelkedő munkásságát. Az idézett tanulmánygyüjteményt olvasva hiteles képet kapunk PÉNTEK JÁNOS különböző tematikájú írásaiból, s érzékelhetjük, hány területen szólalt meg a szakmabelieknek szánt írásoktól az erdélyi magyar szülőket megszólító körleveléig. Nem túlzás azt mondanunk, hogy PÉNTEK JÁNOS az erdélyi magyar nyelv ügyének, tehát az erdélyi magyarságnak a mindenes szolgálója. A kisebbségi kétnyelvüségről rengeteg tapasztalata van, hiszen ebben a közegben él, ezt is kutatja. Ezzel kapcsolatban fogalmazott így a szülőknek írt körlevelében: „,[a] két nyelv ismeretének, a kétnyelvüségnek akkor van [...] haszna, ha mindkét nyelvben magas szintü, és ha annak alapja az anyanyelv" (2015-2016. 2: 19).

A születésnapi köszöntőnek nem feladata az ünnepelt munkásságának részletes méltatása. Amilyen hatalmas PÉNTEK JÁNOS eddigi, publikált formában elérhető tudományos teljesítménye, eleve lehetetlen is volna - a terjedelmi korlátok illendő betartásának íratlan szabályáról nem is beszélve - számba venni legfontosabb eredményeit. S akkor nem is szóltunk széles körű tudományszervezői, utánpótlás-nevelő, tudománypolitikai és tudományos ismeretterjesztő tevékenységéről. Ars poeticaszerủen, a tudomány müvelői számára elvi fontosságú elvárásként fogalmazta meg, hogy ,a tudományos vizsgálatban nincs helye sem az óvatoskodásnak, sem a lojalitás kinyilvánításának, sem az ellenszenvnek, sem a féltésnek. A lehetőségek szerint elfogulatlannak kell lennie" (in: BoLLA szerk. 2009. 3: 281).

Nagyrészt az ő nevéhez füződik az utóbbi évek két kiemelkedő erdélyi nyelvtudományi alkotása. Röviden essék szó róluk! PÉNTEK JÁNOSnak - aki dialektológusként és etnobotanikusként indult a pályán - köszönhető nagyrészt, hogy 2016-2018-ban megjelent 
a legarchaikusabb magyar nyelvjárási régiónak, a moldvainak a régóta remélt, várt háromkötetes szótára (A moldvai magyar tájnyelv szótára). Ez a magisztrális szótár tartalmazza mindazokat a moldvai magyar nyelvjárásokból/nyelvhasználatból származó szavakat, amelyeket korábban följegyeztek. A nagyrészt történeti, tehát nem friss gyüjtésü anyagot tartalmazó szótár ily módon eminensen leletmentő munka. Magától értődik, hogy tele van közmagyar szemmel nézve ismeretlen szavakkal. Közelebbről nézve feltünik a jelentésbeli regionalizmusok sokasága (a szótár ezért szemantikai, kognitív vizsgálatokra fokozottan érdemes). Követendő lexikográfiai újítást vezetett be a magyar dialektológiában PÉNTEK JÁNOS azzal, hogy a szokásos onomasziológiai rendezőelv (tehát a szavak betürendje) szerinti szólajstromozását külön kötetben kiegészítette a fogalmi elrendezésen alapuló szemasziológiai szólistával. Körösfői gyermekkori emlékeinek köszönhető néprajzi érdeklődéséből következett, hogy az utóbbi kötetet gazdag és színvonalas, szemet gyönyörködtető, néprajzi szempontból különösen is jelentős fénykép- és rajzmellékletek sokaságával tette még értékesebbé. Ha bárki föllapozza a három kötetet, a benne látható sok-sok kitünő, a moldvai népéletről tájékoztató fénykép és ábra önmagában is vonzó lehet a hagyományos népi kultúra iránt érdeklődők számára. De meggyőződhet arról is, mennyi energiát, időt kellett a szerkesztőnek ráfordítania, míg az utolsó pontot is kitehette munkája végére (ami ez esetben a bevezető fejezet lezárását jelenthette). Érdemes idéznem következő mondatait: „Több mint másfél évtizede élek egy szómúzeum bűvöletében, a moldvai magyar szavak múzeumában. A kolozsvári tanszék, amellyel egész életem összekapcsolódik, maga is egy szómúzeum, ennek egyik tárlója az a sokfiókos szekrény, amelyben a moldvai szavak cédulái állnak, és amelyekből A moldvai magyar tájnyelv szótára összeállt. [...] a figyelmes olvasó, a szótárt forrásként használó kutató a betük rendjében megtalálja a régi szavak kincseit, a tárgyi és szellemi kultúra nyelvi lenyomatait, a mély értékeket őrző népi vallásosság vallomásait, a lélek nyelvi rezdüléseit, a finom érzékenységet. Az a nyolc évszázad, amely e magyar nyelvváltozat mögött áll, és különösen az elmúlt másfél évszázad kemény asszimilációs nyomása, szintén tükröződik a szótár anyagában" (2019: 16). Kell ennél beszédesebb ajánlás a szóban forgó opushoz?

A magyar nyelv Romániában (Erdélyben) címü, BENŐ ATTILÁval társszerzőségben született könyv (2020) magas színvonalú, mintaszerü, a maga nemében enciklopedikus jellegű szociolingvisztikai összegzés, méltó lezárása a KONTRA MIKLÓs szerkesztette A magyar nyelv a Kárpát-medencében a XX. század végén címü sorozatnak. Címe alapján kizárólag nyelvi kérdésekkel foglalkozó könyvre gondolhatnánk. A kötet azonban ember (társadalom) és nyelv egymást feltételező összefüggéséből kiinduló, az (erdélyi) magyar anyanyelvközösség történetét és jelen állapotát is sokoldalúan bemutató szociolingvisztikai szintézis. Bizonyságul, egyszersmind tájékoztatásul megemlítek néhány témakört a kötetből: a magyarok megtelepedése Erdélyben, néprajzi tájak, reformáció és anyanyelvüség, államiságból államnélküliségbe, lélekszám, nyelvhasználati színterek, kisebbségpolitika az oktatásban, a magyar nyelv a felsőoktatásban, névjog, a földrajzi nevek szabályozása, tanulók, pedagógusok, könyvkiadás, hitélet, elitkultúra, a szépirodalom nyelve, szaknyelvek, leépülés a 20. században, a közélet magyarnyelvüsége, kétnyelvüség, a nyelvek presztízse, kontaktusnyelvészeti kérdések, nyelvi tervezés, a magyar nyelv a kibertérben. A könyv olvastán természetes az óhaj: jó lenne, ha eljutna mindenkihez, akit érdekel Erdély, az ottani magyarság és anyanyelve. A könyv friss, hiteles forrás a sok tudománytalansággal találkozó nagyközönség számára is! Adatainak hitelességével 
és sokaságával, tárgyilagos leírásával hozzásegít a valóság talajára állítani azon olvasóit, akik illúziókat is táplálva gondolnak az erdélyi magyarok helyzetére. Hozzásegít tehát a józanabb önismeret kialakításához. Nem rejti véka alá azt sem, hogy bizony „térbeli kiterjedtségében és arányaiban [...] kimutatható a magyar népesség folyamatos nyelvcseréje és asszimilációja" (2015-2016. 1: 23).

PÉNTEK JÁNOS a nyelvi változatosság kitünő ismerője, kutatója és támogató hirdetője: ,a nyelvben minden változatnak megvan a maga szerepe, és csak ebben a teljességben igazodhat a beszélő és a közösség igényeihez, közlési szándékaihoz. Ezért fontosak a hagyományba visszanyúló és a regionális nyelvi tartalékok, a nagy nyelvi tömbök és a szórványok egyaránt, a szépirodalom mindig inspiráló nyelvi mintái, a szaknyelvek precíz terminusai. Ezek mind hozzátartoznak a nyelv gazdagságához, funkcionális teljességéhez" (2015-2016. 1: 25) - mondta 2014-ben a Petőfi Irodalmi Múzeumban elhangzott ünnepi előadásában, melynek ezt a találó, szokatlanságával is figyelemfelhívó címet adta: Nyelvünk táji változatosságának dicsérete (i. m. 185). A szórványban élőkről pedig azt az igazságot mondta ki: ,a beszélő - utolsó közösségi kötelékeként, korábbi azonosságának utolsó jegyeként is - a maga nyelvjárásában marad meg, ameddig megmarad" (20152016. 1:190). Sokat tanulhatunk írásaiból az erdélyi (romániai), illetőleg általában is a kisebbségi nyelvi sorsról és következményeiről. Több írásában is foglalkozik a nyelvmegtartás és az identitás kapcsolatával. Végkövetkeztetése: ,a Kárpát-medencei magyar identitásnak nagyon fontos eleme a nyelv. Ebböl következik, hogy az identitásmegörzésnek alapvető feltétele a nyelvmegtartás" (2015-2016. 1: 347).

A szokottnál talán gyakoribb, tőle vett idézetekkel egy célom volt: hitelesen hozzájárulni az embernek és a tudósnak a jellemzéséhez.

Ö indította újra a kolozsvári egyetemen a néprajz szakot, az MTA Kolozsvári Akadémiai Bizottságának elnöke (2007 és 2014 között), a kolozsvári Babeş-Bolyai Egyetem tanszékvezető egyetemi tanára (1990 és 2017 között), akit a Magyar Köztársasági Érdemrend Középkeresztjével és Bethlen Gábor-díjjal tüntették ki, a Debreceni Egyetem díszdoktora, a Szabó T. Attila Nyelvi Intézet alapítója (2001), az Anyanyelvápolók Erdélyi Szövetségének vezetője, 2009 óta a Magyar Nyelvtudományi Társaság tiszteletbeli tagja, folyóiratunk nemzetközi tanácsadó testületének is tagja, mindig szívesen látott szerzője... A sort folytathatnám.

Amikor most köszöntöm öt a Magyar Nyelvtudományi Társaság nevében mint tiszteletbeli tagunkat, pályatársunkat, egyúttal köszönetet is mondok neki mindazért, amit a magyar nyelv sokoldalú kutatása és az erdélyi magyarság, illetve az ottani magyar nyelv vizsgálata és fenntartása érdekében tett és tesz. Szívből gratulálunk lenyügöző teljesítményéhez, és kívánunk neki változatlan lendületet és további sok sikert. Ö tudja legjobban, hogy ez elsődlegesen közérdekből fontos. Ezért, kedves János, nyomatékos kívánságunk születésnapodon: ad multos annos!

\section{Hivatkozott irodalom}

Bolla KÁLMÁN szerk. 2009. Magyar nyelvész pályaképek és önvallomások. 3. [K. n.] Budapest. (A Péntek Jánosról szóló fejezet: 278-305.)

PÉNTEK JÁNOS 2015-2016. Történések a nyelvben a keleti végeken. 1-2. Erdélyi MúzeumEgyesület, Kolozsvár. 
PÉNTEK JÁNOS szerk. 2016-2018. A moldvai magyar tájnyelv szótára. I/1. A-K és I/2. L-ZS: Moldvai magyar -közmagyar rész. II. Közmagyar - moldvai magyar rész. Erdélyi MúzeumEgyesület, Kolozsvár.

PÉNTEK JÁNOS 2019. A hüség próbája: megmaradás a nyelvben. Honismeret 2019/1: 13-16. PÉNTEK JÁNOS - BENŐ ATTILA 2020. A magyar nyelv Romániában (Erdélyben). Erdélyi MúzeumEgyesület - Gondolat Kiadó, Kolozsvár-Budapest.

KISS JENÖ

ELTE Eötvös Loránd Tudományegyetem

\section{Voigt Vilmos 80 éves*}

Voigt Vilmost, az ELTE professzor emeritusát, azaz VV tanár urat még éppen köszönthette a Magyar Szemiotikai Társaság 2020-ban, a járványveszély miatti korlátozások bevezetése előtt személyesen, barátok gyürüjében a Petőfi Irodalmi Múzeum Károlyi éttermében. Tudom, hogy a Magyar Nyelvtudományi Társaság is tervezett ünnepi ülést, de ezt már nem tarthattuk meg. Ezért ezzel az írással köszöntöm a Magyar Nyelvtudományi Társaság nevében is.

Hadd kezdjem személyes emlékkel! Elöttem van az első találkozásunk, éppen 40 éve, amikor fölvételiztem néprajz szakra. Akkoriban, ha egy kétszakos bölcsész kiváló eredménnyel tanult, belső felvételivel fölvehetett egy harmadik szakot. Ez volt a szándékom. Tálasi István professzor, a Tárgyi néprajzi tanszék éppen akkor leköszönő vezetője elbeszélgetett velem, és azt mondta, rendben, de kell még Voigt Vilmos tanár úr ajánlása is, aki éppen akkor vette át a Folklore tanszék vezetését. Átmentem a könyvtárba, ott Winkler Zsuzsa néninél érdeklődtem, hogy hol találom Voigt tanár urat. Én vagyok az, mondta Voigt tanár úr, aki ott ült, és éppen aláírt valamit. És szó nélkül aláírta a felvételimet is. Nem fölvételiztetett. Semmit se kérdezett. Ha megtette volna, lehet, hogy másként alakul a sorsom, s a most következőket se írhattam volna le.

Voigt Vilmos tanár úrral 80. születésnapja kapcsán 52 perces film készült: A Mount Everest tetején - sokféle azonosság. Voigt Vilmossal beszélget Verebélyi Kincső, rendezte: Tari János. Ezért életrajzát csak jelzésszerüen ismertetem: 1940. január 17-én Szegeden született. 1963-ban végzett az ELTE néprajz szakán, s ettől kezdve a tanszék gyakornoka, tanársegéde, docense, majd professzora, húsz éven át tanszékvezetője, a Néprajzi Intézet igazgatója, a Magyar és összehasonlító folklorisztikai doktori iskola alapítója. 2010-ben vonult nyugdíjba, azóta professzor emeritus. Voigt Vilmost a világ szinte minden részén ismerik antropológusok, folkloristák, nyelvészek; számos nemzetközi és magyar szervezet választott vagy tiszteletbeli tagja: International Association for Semiotic Studies, Folklore Fellows, European Centre for Traditional and Regional Cultures,

*Első változata elhangzott 2020. február 12-én a Magyar Szemiotikai Társaság által a Petőfi Irodalmi Múzeum Károlyi éttermében tartott köszöntésen. A további, finn és észt köszöntések a Szemiotikai Tájékoztató 2020/1. számában olvashatók: http://www.szemiotika.hu/feltoltes/2020/02/ szemtaj2001.pdf (2021. 05. 31.) 